\title{
Antitumor effect and mechanism of an ellagic acid derivative on the HepG2 human hepatocellular carcinoma cell line
}

\author{
HUI ZHANG, ZENG-JUN GUO, WEN-MING XU, XIAO-JUAN YOU, \\ LING HAN, YAN-XIA HAN and LIU-JIANG DAI \\ Faculty of Pharmacy, Medical College of Xi'an Jiaotong University, Xi'an, Shaanxi 710061, P.R. China
}

Received May 25, 2013; Accepted November 26, 2013

DOI: $10.3892 / \mathrm{ol} .2013 .1740$

\begin{abstract}
In the present study, to identify the effective components of Chinese traditional herbs, Euphorbia hylonoma Hand.-Mazz. (Euphorbiaceae), a folk herb that has been used among the Qinling mountain area for hundreds of years, was investigated. 3,3'-Di-O-methyl ellagic acid-4'-O- $\beta$-d-xylopyranoside (JNE2), an ellagic acid derivative, was isolated from the acetone extract of the herb and its antitumor activity against human hepatoma HepG2 cells was detected in vitro. The results showed that JNE2 inhibited the proliferation of HepG 2 cells in a dose- and time-dependent manner and blocked the cell cycle at the G1/S phase. A high dosage of JNE2 induced apoptosis of the tumor cells, but no significant differences were identified between the treatment groups. The invasiveness of HepG2 cells was also inhibited by JNE2. The mechanism of the antitumor effect of JNE2 at the molecular level was presumed to be due to the upregulation of the protein expression of Bax and caspase-3, and the downregulation of the protein expression of $\mathrm{Bcl}-2$ and $\mathrm{CCND} 1$. The results suggested that JNE2 is a potential antitumor agent that merits further investigation.
\end{abstract}

\section{Introduction}

Euphorbia hylonoma Hand.-Mazz. (Euphorbiaceae), commonly known as Jiu Niuzao, has long been used as a folk medicine in China. It grows wildly in the Northwestern region of China and is used in antineoplastic intervention, as well as in the treatment of hepatocirrhosis, edema and incontinence (1). The bioactive and chemical constituents from the Euphorbia genus have been widely studied (2-7). It has been previously reported that several Euphorbia species are used in the treatment of skin diseases, gonor-

Correspondence to: Professor Zeng-Jun Guo, Faculty of Pharmacy, Medical College of Xi'an Jiaotong University, 76 West Yanta Road, Xi'an, Shaanxi 710061, P.R. China

E-mail:guozj@mail.xjtu.edu.cn

Key words: antitumor activity, ellagic acid derivative, Euphorbia hylonoma Hand.-Mazz., human hepatoma HepG2 rhea, migraines (8) and cancerous conditions (9-11). Previous studies have reported the isolation of the chemical constituents from this plant, including tannins, ferulic acid esters and sesquiterpenoids $(12,13)$. There have also been studies on the pharmacognosy of this plant $(14,15)$.

However, studies concerning the antitumor components from this plant and their mechanisms of action are rare. In the current study, 3,3'-di-O-methyl ellagic acid-4'-O- $\beta$-d-xy lopyranoside(JNE2), an ellagic acid derivative, was isolated from Euphorbiaceae during the anticancer screening study of traditional Chinese medicine (TCM). After analyzing its chemical features and comparing the spectral data with those of previous studies $(16,17)$, this compound was identified as JNE2. The present study investigated the cytotoxic activity and the antitumor mechanisms of JNE2. Cell cycle, apoptosis and western blot analyses and cell invasion assay were employed, and the HepG2 human hepatoma cell line was adopted as the cell model.

\section{Materials and methods}

General materials. Nuclear magnetic resonance (NMR) spectra were recorded on a Bruker Avance III 500 NMR spectrometer (Bruker Corporation, Billerica, MA, USA) with tetramethylsilane as an internal standard. High-resolution electrospray ionization mass spectrometry was conducted using a Micromass Autospec-Ultima TOF mass spectrophotometer (Micromass UK Ltd., Altrincham, UK). The melting point was acquired using micro melting point apparatus (Beijing Tech Instrument Co., Ltd., Beijing, China). The materials used for column chromatography (CC) were silica gel $\left(\mathrm{SiO}_{2}\right.$; 200-300 mesh; Qingdao Marine Chemical Factory, Qingdao, China) and Sephadex LH-20 (18-111 $\mu \mathrm{m}$; GE Healthcare, Amersham, UK). Thin-layer chromatography (TLC) was conducted using glass precoated with silica gel (GF254; 10-40 mm; Qingdao Marine Chemical Factory).

Plant material. The roots of Euphorbia hylonoma were collected from Qinling Mountain, Shaanxi, China, in September 2010 and were identified by Professor Juxian Lu, Faculty of Pharmacy, Medical College of Xi'an Jiaotong University (Xi'an, China). The voucher specimen was retained at the Department of Pharmacy, Medical School of Xi'an Jiaotong University for future reference. 
Cell culture. The HepG2 human hepatoma cell line was obtained from the Shanghai Institute of Biochemistry and Cell Biology, Chinese Academy of Sciences (Shanghai, China). HepG2 cells $\left(5.0 \times 10^{4}\right.$ cells $\left./ \mathrm{ml}\right)$ were cultured in RPMI-1640 supplemented with $10 \%$ fetal bovine serum (FBS), containing $2.0 \mathrm{mmol} / \mathrm{l}$ glutamine and $1 \%$ penicillin-streptomycin in $5 \%$ $\mathrm{CO}_{2}$ at $37^{\circ} \mathrm{C}$, and were allowed to adhere for $24 \mathrm{~h}$. The experiments were divided into the following five groups in the cell proliferation assay (MTT assay): Negative control (dimethyl sulfoxide; DMSO); positive control (15 $\mu \mathrm{mol} / 1$ oxaliplatin); low-dosage $(22.5 \mu \mathrm{mol} / 1 \mathrm{JNE} 2)$; middle-dosage (45 $\mu \mathrm{mol} / 1$ JNE2); and high-dosage (90 $\mu \mathrm{mol} / 1 \mathrm{JNE} 2)$. However, the low-dosage group was cut-off in other assays due to its low efficiency in the MTT assay.

Extraction and isolation. The dried and powdered roots (1 kg) of Euphorbia hylonoma were extracted with acetone three times ( $24 \mathrm{~h}$ per extraction) at room temperature to obtain 212 -g extracts. A portion of the acetone extracts $(20 \mathrm{~g})$ was chromatographed on a silica gel (500-g) column. The column was eluted with a gradient of petroleum ether-ethyl acetate (100:1 to 1:100) and methanol. The volume of each elution was $250 \mathrm{ml}$ and underwent TLC inspection. The fractions with the same TLC spectrum behavior were combined to obtain seven fractions, A-G. Subsequently, fraction D (4.3 g) was further isolated on a silica gel column and eluted with petroleum-ether acetate (7:3). Further CC of subfraction B (1.2 g) from fraction D was performed on a Sephadex LH-20 column that was eluted with methanol. Compound JNE2 (0.6 g) was obtained from subfraction B-6. The identification of this compound was performed through the analysis of the spectroscopic features and comparing the spectral data with those of previous studies $(16,17)$. This compound was identified as JNE2 (Fig. 1) as follows as follows: White powder, m.p. $241-243^{\circ} \mathrm{C} ;{ }^{1} \mathrm{H}$ NMR (500 MHz, DMSO-d 6 ) $\delta$ ppm: $7.48(1 \mathrm{H}, \mathrm{d}, J=5.3, \mathrm{H}-5), 7.73$ $(1 \mathrm{H}, \mathrm{d}, J=3.2, \mathrm{H}-5), 4.05\left(1 \mathrm{H}, \mathrm{s}, 3-\mathrm{OCH}_{3}\right), 4.08\left(1 \mathrm{H}, \mathrm{s}, 3-\mathrm{OCH}_{3}\right)$, $10.8(1 \mathrm{H}, \mathrm{s}, 4-\mathrm{OH}) ;{ }^{13} \mathrm{C} \mathrm{NMR}\left(125 \mathrm{MHz}, \mathrm{DMSO}-\mathrm{d}_{6}\right) \delta \mathrm{ppm}$ : 111.07 (C-1), 140.94(C-2), 140.19(C-3), 151.26 (C-4), 111.65 (C-5), 111.82 (C-6), 158.37 (C-7), 114.19 (C-1'), 141.58 (C-2'), 141.98 (C-3'), 152.84 (C-4'), 112.02(C-5'), 112.72(C-6'), 152.40 (C-7'), 101.94(C-1"), 73.09(C-2"), 76.17(C-3"), 69.31(C-4"), $65.84\left(\mathrm{C}-5^{\prime \prime}\right), 61.48\left(3-\mathrm{OCH}_{3}\right), 61.02\left(3^{\prime}-\mathrm{OCH}_{3}\right)$.

3-(4,5-Dimethylthiazol-2-yl)-2,5-diphenyltetrazolium bro mide (MTT) assay. HepG2 cells $\left(2 \times 10^{4}\right.$ cells/well) were seeded in 96-well plates. Following overnight incubation, test substances were added and the incubation was continued at $37^{\circ} \mathrm{C}$ in an atmosphere containing $5 \% \mathrm{CO}_{2}$ for 3 days. Subsequently, $20 \mu \mathrm{l}$ MTT (Sigma-Aldrich, St. Louis, MO, USA) solution (5 g/l) was added into each well and incubated for an additional $4 \mathrm{~h}$. Supernatants were removed and formazan crystals were dissolved in $200 \mu 1$ DMSO. The optical density was measured at $490 \mathrm{~nm}$ using a POLARstar Optima (BMG Labtech GmbH, Ortenberg, Germany).

Cell cycle and apoptosis analysis. Cell seeding and treatment were the same as MTT assay. After three days of treatment, cells were harvested by trypsinization and $1 \times 10^{6}$ cells were counted and used for the analysis. Cells were fixed in ice-cold ethanol overnight at $4^{\circ} \mathrm{C}$ following washing with PBS. The cells were then washed in PBS again and incubated in $1 \mathrm{ml}$ staining solution $(20 \mu \mathrm{g} / \mathrm{ml}$ propidium iodide and $10 \mathrm{U} / \mathrm{ml}$ RNase A) for $30 \mathrm{~min}$ at room temperature. The cells were examined by fluorescence-activated cell sorting (FACS) using a flow cytometer (FACSort; Becton-Dickinson, Franklin Lakes, NJ, USA), and the cell cycle populations were determined using ModFit software (Verity Software House, Turramurra, Australia).

For the analysis of apoptotic cell populations, cells were trypsinized and washed in PBS. Staining with Alexa-Fluor 647 Annexin V (Invitrogen Life Technologies, Carlsbad, CA, USA) and propidium iodide was performed in $20 \mathrm{mmol} / 1 \mathrm{HEPES}$ buffer (pH 7.4), containing $150 \mathrm{mM} \mathrm{NaCl}$ and $2.5 \mathrm{mmol} / \mathrm{C} \mathrm{CaCl}_{2}$, for $15 \mathrm{~min}$ at room temperature. The cells were examined by FACS using a flow cytometer (FACSort; Becton-Dickinson), and the apoptotic populations were determined using ModFit software (Verity Software House).

Cell invasion assay. Cell invasion was evaluated using the Chemicon QCM ${ }^{\mathrm{TM}}$ 24-well collagen-based cell invasion assay (Millipore, Billerica, MA, USA) according to the manufacturer's instructions. In brief, $0.3 \mathrm{ml}$ serum-free medium was added to the interior of each insert to rehydrate the collagen layer for $30 \mathrm{~min}$ at room temperature. The medium was then replaced with $0.3 \mathrm{ml}$ prepared serum-free cell suspension containing $3.0 \times 10^{5}$ cells and the corresponding test substances. Medium (500 $\mu \mathrm{l}$ ) containing 10\% FBS was added to the lower chamber and the cells were incubated for $24 \mathrm{~h}$ at $37^{\circ} \mathrm{C}$. Following this, all non-invaded cells were removed from the interior of the insert and the invaded cells were stained with crystal violet. The stained cells were analyzed on an Olympus fluorescence microscope (BX43; Olympus Corporation, Tokyo, Japan).

Western blot analysis. Cell seeding and treatment were the same as MTT assay. After three days of treatment, cells were harvested and washed in PBS. Cell protein lysates were separated in 10\% SDS-polyacrylamide gels and electrophoretically transferred to polyvinylidene difluoride membranes (Roche Diagnostics, Mannheim, Germany). The lysates were then detected using rabbit polyclonal antibodies that were specific for Bcl-2, BAX, caspase-3 and CCND1 (Santa Cruz Biotechnology, Inc., Santa Cruz, CA, USA) and a commercial ECL kit (Pierce Biotechnology, Inc., Rockford, IL, USA). Protein loading was estimated by human anti- $\beta$-actin monoclonal antibody (Santa Cruz Biotechnology, Inc.).

Statistical analysis. Statistical analysis was performed by one-way ANOVA test followed by Fisher's protected least significant difference post hoc test for multiple comparisons using the StatView program (Abacus Concepts, Berkeley, CA, USA). $\mathrm{P}<0.05$ was considered to indicate a statistically significant difference.

\section{Results}

Cell growth inhibition. To evaluate the antitumor role of JNE2 on human hepatoma cells, MTT and colony formation assays were employed to detect the growth of HepG2 cells at various time points following treatment with JNE2 at various concentrations. The results showed that JNE2 exhibited a growth inhibitory effect on HepG2 cells in a dose- and time-depen- 


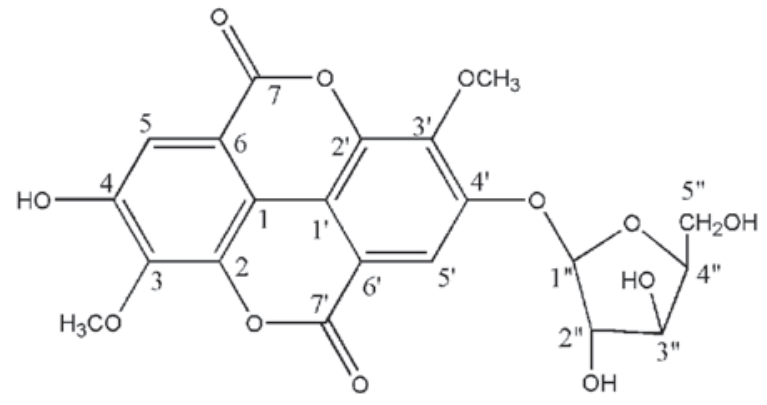

Figure 1. Chemical structure of 3,3'-di-O-methyl ellagic acid-4'-O- $\beta$-dxylopyranoside.

A

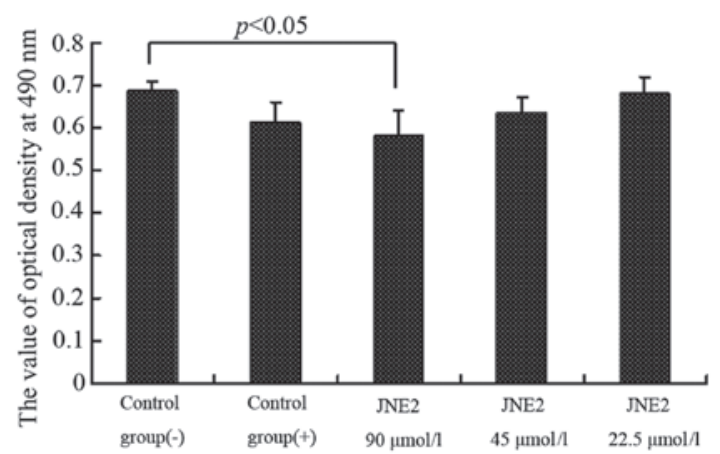

B

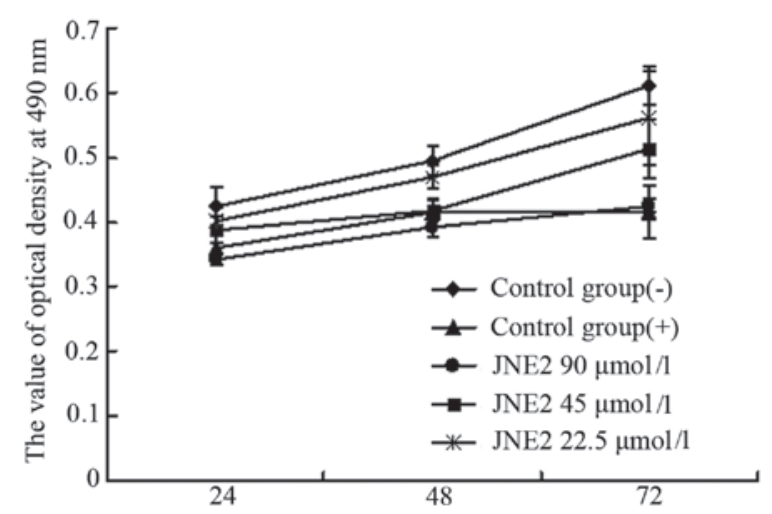

Figure 2.Growth inhibitory effect of JNE2 on HepG2 cells. (A) Dose-dependent effect of JNE2 on HepG2 cells after $24 \mathrm{~h}$ and (B) time-dependent effect of JNE2 on HepG2 cells after 3 days when the cell viability was determined by 3-(4,5-dimethylthiazol-2-yl)-2,5-diphenyltetrazolium bromide assay. JNE2, 3,3'-di-O-methyl ellagic acid-4'-O- $\beta$-d-xylopyranoside.

dent manner. Following $24 \mathrm{~h}$ of treatment, the OD value of the high-dosage group (JNE2, $90 \mu \mathrm{mol} / \mathrm{l}$ ) was significantly lower than that of the negative control group $(\mathrm{P}<0.05)$ and also lower than that of the positive control group, but without significant difference (Fig. 2A). The time-effect curve also demonstrated the antiproliferation ability of JNE2 (Fig. 2B). Furthermore, the colony formation results shown in Fig. 3 confirmed that a high dosage of JNE2 may inhibit the growth of HepG2 cells. These results suggested that JNE2 exhibits an inhibitory effect on the proliferation of hepatoma cells.

JNE2-induces G0/G1 cell cycle arrest. To explore the mechanism underlying JNE2-suppressed cell proliferation, the impact of JNE2 on cell cycle progression was investigated by FACS and the results are presented in Fig. 4A. Following

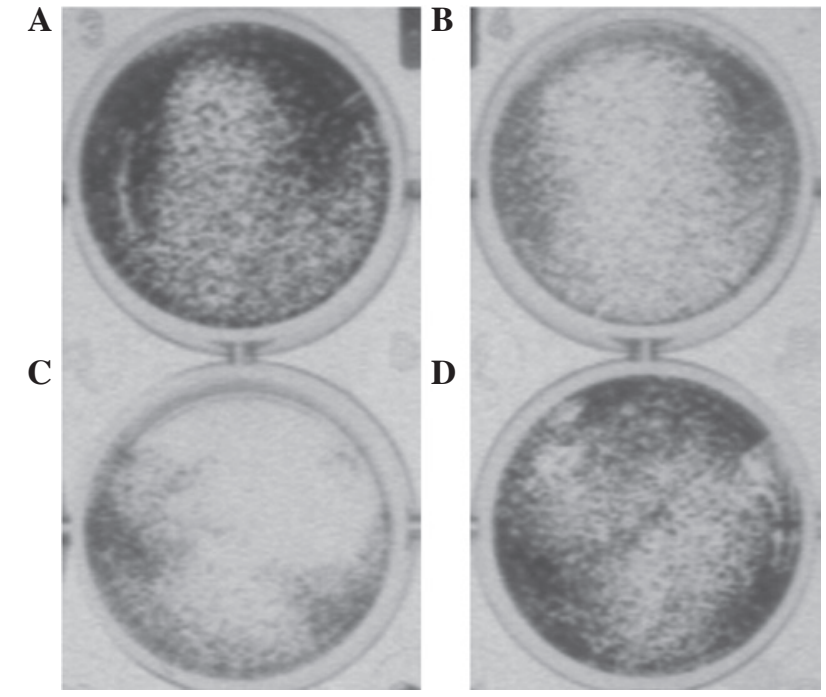

Figure 3. Colony formation of HepG2 cells following treatment with (A) Dimethyl sulfoxide, (B) oxaliplatin and (C) 90 and (D) $45 \mu \mathrm{mol} / 1$ of 3,3'-di-O-methyl ellagic acid-4'-O- $\beta$-d-xylopyranoside for 3 days.

A

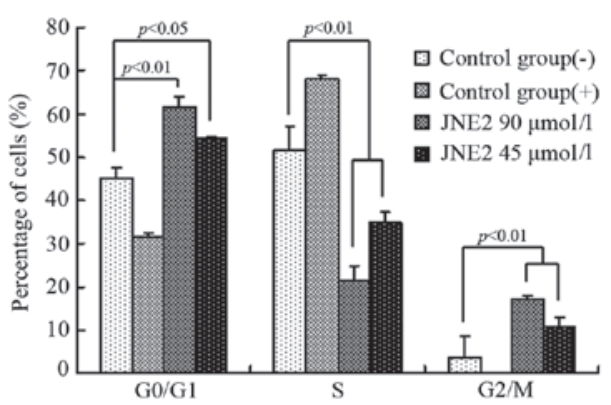

B

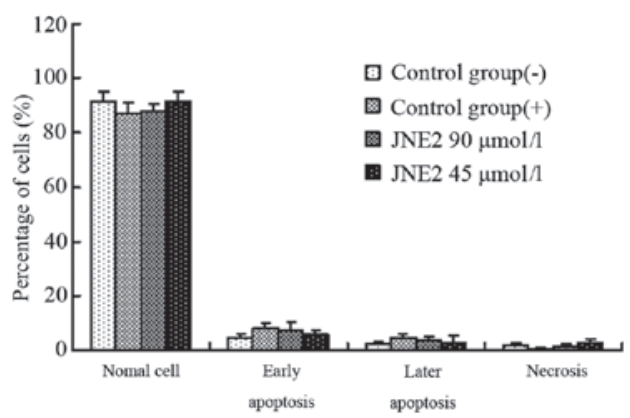

Figure 4. Effect of JNE2 on the cell cycle and apoptosis of HepG2 cells. (A) JNE2-induced G0/G1 cell cycle arrest in HepG2 cells. Effects of JNE2 on the cell cycle distribution following $24 \mathrm{~h}$ of treatment with various concentrations are presented. (B) JNE2-induced apoptosis of human hepatoma HepG2 cells following $24 \mathrm{~h}$ of treatment. The percentages of normal, early and late apoptotic and necrotic cells are presented. JNE2, 3,3'-di-O-methyl ellagic acid-4'-O- $\beta$-d-xylopyranoside.

treatment with high and middle dosages of JNE2, the cell cycle shifted from a high $\mathrm{S}$ phase population to a high $\mathrm{G} 1$ phase population, together with an accumulation of a G2/M phase population. Whereas, little effect on the cell cycle was observed in the control groups. These results indicated that JNE2 blocks the G1/S transition.

JNE2-induces HepG2 cell apoptosis. To examine the effect of JNE2 on apoptosis, hepatoma cells were treated with various 

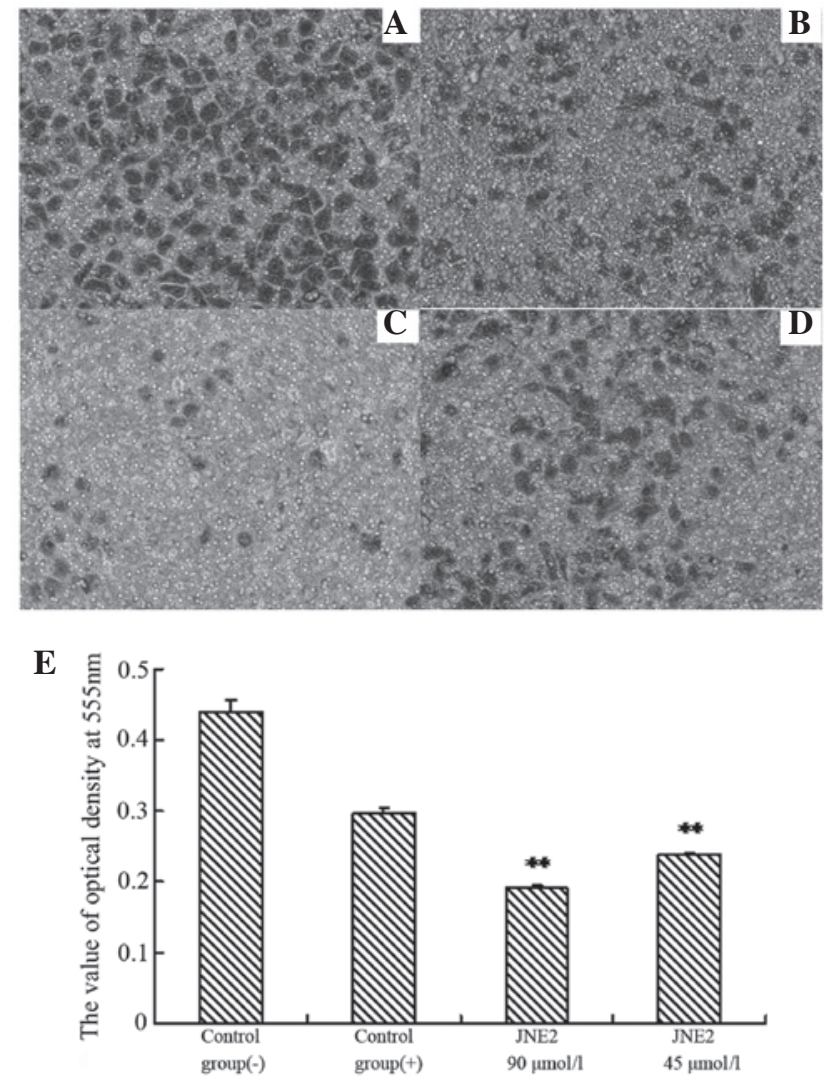

Figure 5. Invasion inhibition effect of JNE2 on HepG2 cells. (A) Control group (-), (B) control group (+) and (C) 90 and (D) $45 \mu \mathrm{mol} / 1$ JNE2-treated groups. (E) OD values of various groups following $24 \mathrm{~h}$ treatment with JNE2 or control. ${ }^{* *} \mathrm{P}<0.01$, vs. negative control.. JNE2, 3,3'-di-O-methyl ellagic acid-4'-O- $\beta$-d-xylopyranoside.

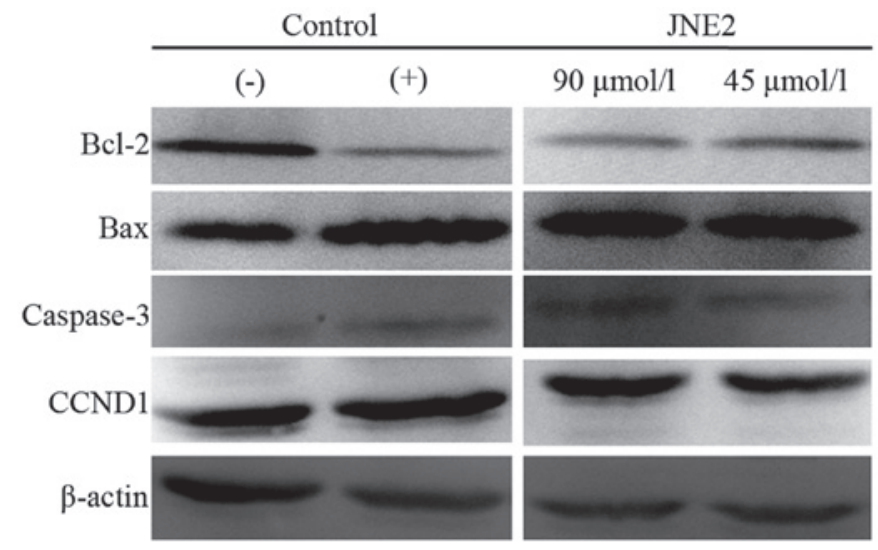

Figure 6. Regulatory effects of JNE2 on apoptosis-related proteins in HepG2 cells. JNE2, 3,3'-di-O-methyl ellagic acid-4'-O- $\beta$-d-xylopyranoside.

concentrations of JNE2. Compared with the cells that were treated with the negative control, the cells that were treated with a high dosage of JNE2 exhibited a similar apoptotic rate to those treated with oxaliplatin, whereas the cells that were treated with $45 \mu \mathrm{mol} / 1 \mathrm{JNE} 2$ exhibited slightly lower apoptotic rates. In the positive and JNE2-treated groups, the number of cells at the early and late stages of apoptosis marginally increased. However, no significant differences were identified (Fig. 4B) between the groups. These results showed that JNE2 induces apoptosis in human hepatoma cells in a dose-dependent manner.
JNE2 inhibits cancer invasion in vitro. Cancer invasion is the process by which cells break away from the primary tumor and migrate through the surrounding tissue. This enables the cancer cells to move into blood vessels and travel through the body, possibly establishing a secondary tumor at an additional site (18). To determine whether JNE2 inhibits invasion, HepG2 cells were treated with various concentrations of JNE2 and the control groups were treated separately. Evidently, the invasion was inhibited by a high concentration of JNE2, whereas, migration was not altered in the cells that were treated with the negative control (Fig. 5). These results markedly suggest that JNE2 inhibits the invasion of HepG2 cells.

Western blot analysis. To clarify the apoptotic mechanism of JNE2 on HepG2 cells, western blot analysis was performed to examine the protein expression levels of Bcl-2, Bax, caspase-3 and CCND1 (cyclin D1). The cells that were treated with JNE2 exhibited upregulated levels of Bax and caspase-3 expression when compared with the negative control cells. This result may explain why JNE2 inhibited the growth of HepG2 cells, and this function may be associated with mitochondrial pathway-induced apoptosis. Conversely, the protein levels of Bcl-2 and CCND1 were decreased with JNE2 treatment (Fig. 6). The apoptotic effect of JNE2 was confirmed by the upregulation of Bax and downregulation of Bcl-2. Based on the G0/G1 arresting capability, the downregulation of CCND1 may provide an explanation. These results suggested that JNE2 may exhibit its apoptotic effect through the upregulation of Bax and caspase-3, and the downregulation of Bcl-2 and CCND1.

\section{Discussion}

Ellagic acid, a type of polyphenol compound that widely exists in herbs and numerous types of fruits and nuts, has recently gained increasing attention, although it was once considered useless in TCM. It has been well established that ellagic acid exhibits anticancer (19), antimutagen (20-22) and antimicrobial functions (23), as well as others. Numerous studies concerning the antimutagen and anticancer effects of ellagic acid were performed in the 1970s (24-27). In previous in vitro and in vivo experiments, ellagic acid has shown significant abilities in inhibiting the growth of a number of types of tumor, such as skin, esophagus and lung, as well as other tumors that are caused by carcinogens (28-32). Its anticancer activities are partially based on the quenching of reactive oxygen species, thereby protecting critical cellular targets (i.e. DNA, proteins and lipids) from oxidative insult (33-35). Ellagic acid may also interfere with intracellular signaling pathways, such as those that regulate proliferation, induce apoptosis and respond to oxidative stress (36-39). In the present study, JNE2, an ellagic acid derivative that was isolated from a traditional Chinese herb, Euphorbia hylonoma Hand.-Mazz. (Euphorbiaceae), showed significant antitumor effects on the HepG2 human hepatocellular carcinoma cell line. The antitumor mechanisms of JNE2 were also investigated.

The results of the current study showed that JNE2 may inhibit the proliferation of HepG2 cells. Specifically, JNE2 affected the cell cycle by arresting the cells in the G0/G1 phase, thus, inducing apoptosis. Cancer cell invasion was also inhibited by JNE2, particularly at a high concentration $(90 \mu \mathrm{mol} / \mathrm{l})$. 
Overall, these results demonstrated the outstanding antitumor ability of JNE2. The regulatory effects of JNE2 upon apoptosis-related protein targets, including Bcl-2, Bax, caspase-3 and CCND1, were measured to determine its antitumor mechanism at the molecular level.

Bcl-2 family proteins that comprise proapoptotic proteins (such as Bax, Bad and Bid) and antiapoptotic proteins (such as $\mathrm{Bcl}-2$ and $\mathrm{Bcl}-\mathrm{xL}$ ) tightly regulate the mitochondrial apoptosis pathway. A number of anticancer drugs trigger mitochondria-mediated apoptosis in cancer cells through the downregulation of $\mathrm{Bcl}-2 / \mathrm{Bcl}-\mathrm{xL}$ or the upregulation of $\mathrm{Bax} / \mathrm{Bad} / \mathrm{Bid}$. Bcl-2 is an antiapoptosis gene (40-44) and is closely associated with cellular apoptosis $(45,46)$, as well as with the mitochondrion $(47,48)$. Bax induces cellular apoptosis and the ratio of $\mathrm{Bcl}-2 / \mathrm{Bax}$ is the determining factor of antiapoptosis for cells (49). The results of the present study showed that JNE2 treatment significantly upregulated the expression of Bax protein and downregulated that of $\mathrm{Bcl}-2$. This suggested that JNE2 acts on the Bcl-2/Bax genes to exert its apoptotic effect.

Caspases, a family of cysteine acid proteases, act as important mediators of apoptosis. They are induced by various stimuli and contribute to the overall apoptotic phenotype by cleaving various cellular substrates (50-52). Caspase-3, a key regulatory protease upon which a number of signaling pathways merge for the execution of apoptosis, is involved in apoptosis induced by Bcl-2/Bax, p38 and JAK-STAT $(53,54)$. In the current study, the protein expression of caspase- 3 was detected in HepG 2 cells following treatment with JNE2 and the upregulated effect was identified. These results suggested that JNE2 induced the apoptosis of human hepatoma HepG2 cells via the mitochondrial pathway.

CCND1 is a cell cycle control protein that mainly affects G1 progression and G1/S transition. It forms complexes with CDK4 and CDK6, and additionally with RB1. The phosphorylation of RB1 by CCND1/CDK4 prevents cell cycle arrest at the G1/S start point. The overexpression of CCND1 causes oncogenesis due to its stimulation of the expression of Bcl-1, which accelerates cell transition through the G1 phase. Therefore, JNE2 shows the ability to block the G1/S phase transition by downregulating the expression of CCND1.

However, among the downregulated and upregulated expression ratios of $\mathrm{Bcl}-2 / \mathrm{Bax}$, caspase-3 and CCND1, the predominant mechanism by which JNE2 induces mitochondria-mediated apoptosis in HepG2 cells is uncertain and other regulatory mechanisms, including at the receptor level, require further investigation.

\section{Acknowledgements}

The present study was supported by grants from the National 863 Plan (no. 2012AA02A400) and the National Natural Science Foundation of China (no. 81172957).

\section{References}

1. Jiangsu New Medical College: Dictionary Traditional Drugs. Shanghai Scientific and Technical Publishers, Shanghai, pp41, 1993.

2. Whelan LC and Ryan MF: Ethanolic extracts of Euphorbia and other ethnobotanical species as inhibitors of human tumour cell growth. Phytomedicine 10: 53-58, 2003.
3. Bruni R, Muzzoli M, Ballero M, Loi MC, Fantin G, Poli F and Sacchetti G: Tocopherols, fatty acids and sterols in seeds of four Sardinian wild Euphorbia species. Fitoterapia 75: 50-61, 2004.

4. Hore SK, Ahuja V, Mehta G, Kumar P, Pandey SK and Ahmad AH: Effect of aqueous Euphorbia hirta leaf extract on gastrointestinal motility. Fitoterapia 77: 35-38, 2006.

5. Shi HM, Williams ID, Sung HH, Zhu HX, Ip NY and Min ZD: Cytotoxic diterpenoids from the roots of Euphorbia ebracteolata. Planta Med 71: 349-354, 2005.

6. Ruan HL, Zhang Y and Zhang YH: Studies on constituents from roots of Euphorbia hylonoma. Zhongguo Zhong Yao Za Zhi 31: 742-744, 2006 (In Chinese).

7. Cao D, SU YL and Yang JS: Triterpene constituents from Euphorbia nemtocypha Hand-Mazz. Yao Xue Xue Bao 27: 445-451, 1996 (In Chinese).

8. Chaabi M, Michel VF, Frossard N, Randriantsoac A, Andriantsitohainad R and Lobstein A: Anti-proliferative effect of Euphorbia stenoclada in human airway smooth muscle cells in culture. J Ethnopharmacol 109: 134-139, 2007.

9. Valente C, Pedro M, Duarte A, Nascimento MS, Abreu PM and Ferreira MJ: Bioactive diterpenoids, a new jatrophane and two ent-Abietanes, and other constituents from Euphorbia pubescens. J Nat Prod 67: 902-904, 2004.

10. Zhang WF, Cui Z and Zhu Q: Cytotoxicity and antiviral activity of the compounds from Euphorbia kansui. Planta Med 64 754-756, 1998.

11. YasukawaK,Akihisa T, YoshidaZY and TakidoM:Inhibitory effect of euphol, a triterpene alcohol from the roots of Euphorbia kansui, on tumor promotion by 12-O-Tetradecanoylphorbol-13-acetate in two-stage carcinogenesis in mouse skin. J Pharm Pharmacol 52: 119-124, 2000.

12. Guo ZJ, Zhu R, Lu JX and Li YL: Chemical constituents of Euphorbia hylonoma Hand. -Mazz. Zhongguo Zhongyao Zazhi 20: 744-745, 1995 (In Chinese).

13. Ruan HL, Zhou XF, Zhang YH, Pi HF, Wu JZ and Sun HD: Ferulic acid esters from Euphorbia hylonoma. Fitoterapia 78: 72-73, 2007.

14. Guo ZJ, Lu Juxian, Li YL, et al: Studies on pharmacognosy of Euphorbia hylonoma Hand-Nazz. J Xi'an Med Univ 3: 313-315, 318, 1996 (In Chinese).

15. Guo ZJ, Lu X, Li YL and Zhu R: The studies on resource of Euphorbia genus in Shaanxi province. Northwest Pharm J 11 (Suppl 1): 6-7, 1996.

16. Liu RH, Chen LL and Kong LY: Ellagic Acid Derivatives from the Stem Bark of Sapius sebiferum. Zhong Guo Yao Ke Da Xue Xue Bao Bian Ji Bu 5: 370-373, 2002 (In Chinese).

17. Hong YX and Wei GY: Studies on the chemical constituents from leaves of Diplopanax stachyathus. Zhong Cao Yao Bian Ji Bu 2: 125-127, 2004 (In chinese).

18. Duffy MJ, McGowan PM and Gallagher WM: Cancer invasion and metastasis: changing views. J Pathol 214: 283-293, 2008.

19. Maas JL and Galletta GJ: Ellagic acid, an anticarcinogen in fruits, especially in strawberries: a review. Hortscience 26: 10-14, 1991.

20. Thresiamma KC, George J and Kuttan R: Protective effect of curcumin, ellagic acid and bixin on radiation induced genotoxicity. J Exp Clin Cancer Res 17: 431-434, 1998.

21. Mandal S and Stoner GD: Inhibition of N-nitrosobenzylmethylamine-induced esophageal tumorigenesis in rats by ellagic acid. Carcinogenesis 11: 55-61, 1990.

22. Sohn EH, Koo HJ, Hang DT, et al: Protective effects of ellagic acid on ethanol-induced toxicity in hepatic HepG2 cells. Mol Cell Toxicol 9: 249-256, 2013.

23. Lu HF, Tsou MF, Lin JG, Ho CC, Liu JY, Chuang JY and Chung JG: Ellagic acid inhibits growth and arylamine $\mathrm{N}$-acetyltransferase activity and gene expression in Staphylococcus aureus. In Vivo 19: 195-199, 2005.

24. Sayer JM, Yaji H, Wood AW, et al: Extremely facile reaction between the ultimate carcinogen benzo[a]pyrene-7,8-diol 9,10epoxide and ellagic acid. J Am Chem Soc 104: 5562-5564, 1982.

25. Take Y, Imouye Y, Nakamura S, et al: Comparative studies of the inhibitory properties of antibiotics on human immunodeficiency virus and avian myeloblastosis virus reverse transcriptases and cellular DNA polymerases. J. Antibiot (Tokyo) 42: 107-115, 1989.

26. Stoner GD and Morse MA: Isothiocyanates and plant polyphenols as inhibitors of lung and esophageal cancer. Cancer Lett 114: 113-119, 1997.

27. Narayanan BA, Geoffroy O, Willingham MC, Re GG and Nixon DW: P53/p21 (WAF1/CIP1) expression and its possible role in G1 arrest and apoptosis in ellagic acid treated cancer cells. Cancer Lett 136: 215-221, 1999. 
28. Ahn D, Putt D, Kresty L, Stoner GD, Fromm D and Hollenberg PF: The effects of dietary ellagic acid on rat hepatic and esophageal mucosal cytochromes P450 and phase II enzymes. Carcinogenesis 17: 821-828, 1996.

29. Falsaperla M, Morgia G, Tartarone A, Ardito R and Romano G: Support ellagic acid therapy in patients with hormone refractory prostate cancer (HRPC) on standard chemotherapy using vinorelbine and estramustine phosphate. Eur Urol 47: 449-454, 2005.

30. Labrecque L, Lamy S, Chapus A, et al: Combined inhibition of PDGF and VEGF receptors by ellagic acid, a dietary-derived phenolic compound. Carcinogenesis 26: 821-826, 2005.

31. Arulmozhi V, Pandian K, and Mirunalini S: Ellagic acid encapsulated chitosan nanoparticles for drug delivery system in human oral cancer cell line (KB). Colloids Surf B Biointerfaces 110 313-320, 2013.

32. Rommel A and Wrolstad RE: Ellagic acid content of red rasp2 berry juice as influenced by cultivar, processing, and environ2 mental factors. J Agric Food Chem 41: 1951-1960, 1993.

33. Rafter JJ: Scientific basis of biomarkers and benefits of functional foods for reduction of disease risk: cancer. Br J Nutr 88 (Suppl 2): S219-S224, 2002.

34. Potter JD: Cancer prevention: epidemiology and experiment. Cancer Lett 114: 7-9, 1997.

35. Roy M, Chakrabarty S, Sinha D, Bhattacharya RK and Siddiqi M: Anticlastogenic, antigenotoxic and apoptotic activity of epigallocatechin gallate: a green tea polyphenol. Mutat Res 523-524 $33-41,2003$.

36. Kong AN, Owuor E, Yu R, Hebbar V, Chen C, Hu R and Mandlekar S: Induction of xenobiotic enzymes by the MAP kinase pathway and the antioxidant or electrophile response element (ARE/EpRE). Drug Metab Rev 33: 255-271, 2001.

37. Park AM and Dong Z: Signal transduction pathways: targets for green and black tea polyphenols. J Biochem Mol Biol 36: 66-77, 2003.

38. Loo G: Redox-sensitive mechanisms of phytochemical mediated inhibition of cancer cell proliferation. J Nutr Biochem 14: 64-73, 2003.

39. Heber D and Lu QY: Overview of mechanisms of action of lycopene. Exp Biol Med (Maywood) 227: 920-923, 2002.

40. O'Neill JW and Hockenbery DM: Bcl-2-related proteins as drug targets. Current Med Chem 10: 1553-1562, 2003.

41. Cory S and Adams JM: Killing cancer cells by flipping the Bcl-2/Bax switch. Cancer Cell 8: 5-6, 2005.

42. Fathi NA, Hussein MR, Hassan HI, Mosad E, Galal H and Afifi NA: Glomerular expression and elevated serum Bcl-2 and Fas proteins in lupus nephritis: preliminary findings. Clin Exp Immunol 146: 339-343, 2006.
43. Zhang R, Xue YY, Lu SD, Wang Y, Zhang LM, Huang YL, Signore AP, Chen J and Sun FY: Bcl-2 enhances neurogenesis and inhibits apoptosis of newborn neurons in adult rat brain following a transient middle cerebral artery occlusion. Neurobiol Dis 24: 345-356, 2006.

44. Karlnoski R, Wilcock D, Dickey C, Ronan V, Gordon MN, Zhang W, Morgan D and Taglialatela G: Up-regulation of Bcl-2 in APP transgenic mice is associated with neuroprotection. Neurobiol Dis 25: 179-188, 2007.

45. Bernas T, Asem EK, Robinson JP, Cook PR and Dobrucki JW: Confocal fluorescence imaging of photosensitized DNA denaturation in cell nuclei. Photochem Photobiol 81: 960-969, 2005.

46. Yoshida A, Takemura H, Inoue H, Miyashita T and Ueda T: Inhibition of glutathione synthesis overcomes Bcl-2-mediated topoisomerase inhibitor resistance and induces nonapoptotic cell death via mitochondrial-independent pathway. Cancer Res 66: 5772-5780, 2006.

47. Degli EM: Mitochondria in apoptosis: past, present and future. Biochem Soc Trans 32: 493-495, 2004.

48. Dias N and Bailly C: Drugs targeting mitochondrial functions to control tumor cell growth. Biochem Pharmacol 70: 1-12, 2005.

49. Sedlak TW, Oltvai ZN, Yang E, Wang K, Boise LH, Thompson CB and Korsmeyer SJ: Multiple Bcl-2 family members demonstrate selective dimerizations with Bax. Proc Natl Acad Sci USA 92: 3834-3838, 1995.

50. Riedl SJ and Shi Y: Molecular mechanisms of caspase regulation during apoptosis. Nat Rev Mol Cell Biol 5: 897-907, 2004.

51. Nunẽza G, Benedict MA, Hu Y and Inohara N: Caspases: the proteases of the apoptotic pathway. Oncogene 17: 3237-3245, 1998.

52. Fan TJ, Han LH, Cong RS and Liang J: Caspase family proteases and apoptosis. Acta Biochim Biophys Sin (Shanghai) 37: 719-727, 2005.

53. Dassé E, Bridoux L, Baranek T, Lambert E, Salesse S, Sowa ML, Martiny L, Trentesaux C and Petitfrère E: Tissue inhibitor of metalloproteinase-1 promotes hematopoietic differentiation via caspase-3 upstream the MEKK1/MEK6/p38alpha pathway. Leukemia 21: 595-603, 2007.

54. Lanvin O, Gouilleux F, Mullié C, Mazière C, Fuentes V, Bissac E, Dantin F, Mazière JC, Régnier A, Lassoued K and Gouilleux-Gruart V: Interleukin-7 induces apoptosis of 697 pre-B cells expressing dominant-negative forms of STAT5: evidence for caspase-dependent and -independent mechanisms. Oncogene 23: 3040-3047, 2004. 